\title{
喉頭浮腫を合併したムンプス例
}

\author{
殿内 一弘・山本 昌彦・吉田 友英 \\ 野村 俊之・井関 玩哉・小田＼cjkstart恂*
}

\section{A Case of Mumps with Edema of Larynx}

\author{
Kazuhiro Tonouchi, Masahiko Yamamoto, Tomoe Yoshida, \\ Toshiyuki Nomura and Takuya Iseki \\ (Toho University School of Medicine, Sakura Hospital) \\ Makoto Oda \\ (Toho University)
}

We report a case of mumps with edema of the larynx requiring urgent tracheotomy.

The patient was a 47-year-old man. Dyspnea appeared secondary to swelling in the parotid division. Swelling of the whole face was apparent. There was trismus, and the tonsil and soft palate could not be observed due to severe swelling of the floor of mouth. The tonsilla lingualis, hypopharyngeal walls, and epiglottis showed progressive swelling. Conservative treatment was performed, but an urgent tracheotomy was required due to aggravation of dyspnea. This case was diagnosed as mumps by the clinical course and virus serodiagnosis. We searched the literature for a combination of mumps and edema of the larynx using MEDLINE for 33 years from 1966 to 2000, then performed a second search from 1987 to 2000, using coalescence retrieval, but could not find a previous report of a similar case. There was a description of mumps with edema of larynx in the Nelson Textbook of Pediatrics. This is the first report of mumps accompanied by edema of larynx in Japan. Edema of larynx seemed to be caused by swelling of the tonsilla lingualis and hypopharyngeal wall which appeared to circulatory disturbance.

Key words : mumps, laryngeal edema, dyspnea, tracheotomy

はじめに

ムンプスは，麻疹，風疹，水痘とならんで小児期の伝 染性感染症として代表的なもので，耳下腺の有痛性腫脹 と発熱を主症状とするムンプスウイルスによる全身性伝 染性感染症である. 合併症として膵炎, 乳腺炎, 卵巣炎, 辠丸炎, 無菌性髄膜炎などが挙げられるが, 耳鼻咽喉科 領域ではムンプス難聴が重要な合併症として知られてい る.今回われわれは喉頭浮腫により, 呼吸困難をきたし たために緊急気管切開術を施行したムンプスの 1 例を経 験したので報告する。

\section{症例}

患者：47 歳, 男性.

主訴：呼吸困難.

現病歴: 平成 12 年 12 月 17 日に左耳下部の腫脹およ び圧痛が出現し，19 日には右耳下部の腫脹が出現した。 19 日近医を受診したところ，ムンプスと診断された. 同 日夕方には咽喉頭部の違和感, 就寝時に軽度の息苦しさ がみられた. 20 日朝には吸気時の呼吸困難が出現したた め救急車にて搬送されて来院した.

既往歴：特記すべきことなし. 
家族歷：同年 11 月 27 日，長女がムンプスに罹患。 初診時所見：救急受診時意識は清明であったが，座位 にて吸気時に呼吸困難をきたすため，仰臥位の状態で酸 素吸入をしながら診察した。両側耳下部から顎下部にか けて著明に腫脹し，顔面全体が腫脹していた。開口障害 があり，さらに口腔底の腫脹が激しく扁桃および軟口蓋 は観察できなかった。喉頭ファイバースコープにより咽 喉頭部を観察したところ舌根扁桃，下咽頭側壁，喉頭蓋 が高度に浮腫を呈していた（図 1）。喉頭蓋からファイ バースコープをさらにすすめると，声門，両側披裂部に も強い腫脹がみられた。

経過：呼吸困難のため緊急入院とし，コハク酸ヒドロ コルチゾンナトリウム $300 \mathrm{mg}$ を点滴投与した。喉頭浮 腫が増悪してきたためさらに $300 \mathrm{mg}$ を静脈内投与した が，呼吸困難および喉頭所見は改善しないため緊急気管 切開術を施行した。気管切開術直後の顔面所見および喉 頭所見を図 2 に示す。喉頭所見は，初診時より明らかに 増悪していた。術後, 呼吸困難は改善がみられた。入院 中, 喉頭浮腫の原因精査のため頸部単純 $\mathrm{CT}$ 検査を行っ たが異常は認めなかった。その後, 顔面腫脹および喉頭 浮腫が徐々に改善したため, 12 月 27 日カニニーレを抜 去して気管切開孔閉鎖術を施行した．退院時には耳下部 および䫟下部の腫脤は消失し，喉頭所見も正常であった (図 3).

血液所見：12月 20 日(初診時)の血清アミラーゼ值は

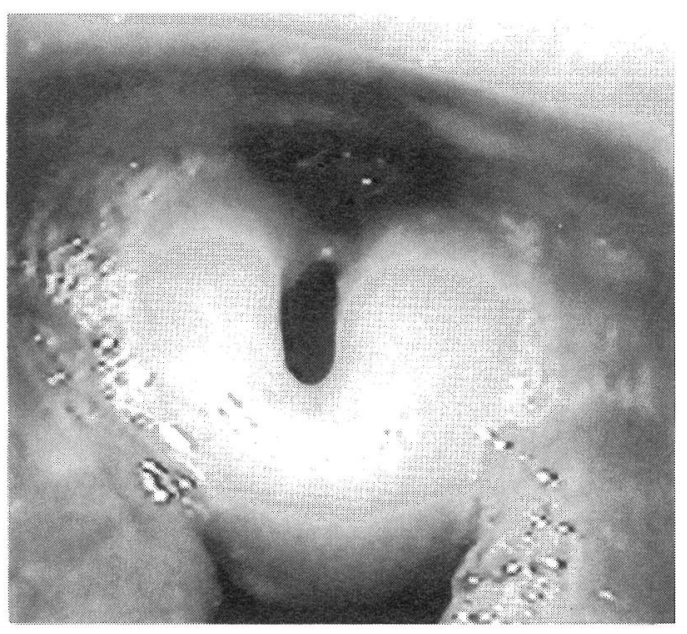

図 1 初診時喉頭所見

舌根扁桃，下咽頭側壁，喉頭蓋の高度の腫脹を認める。

970 と高值を示した。ムンプスウイルス血清学的検查で は，12月 20 日に EIA 法による IgM 抗体が $0.83 ， \operatorname{IgG}$ 抗 体が 37.6 であり，1月 4 日には IgM 抗体 3.5, IgG 抗体 128 といずれも有意な上昇を認めた。

\section{考察}

1. 臨床症状 ${ }^{1)}$ 5)

ムンプスは，おたふくかぜ，流行性耳下腺炎とも呼ば れ，麻疹，風疹，水痘とならんで学校伝染病の一つであ
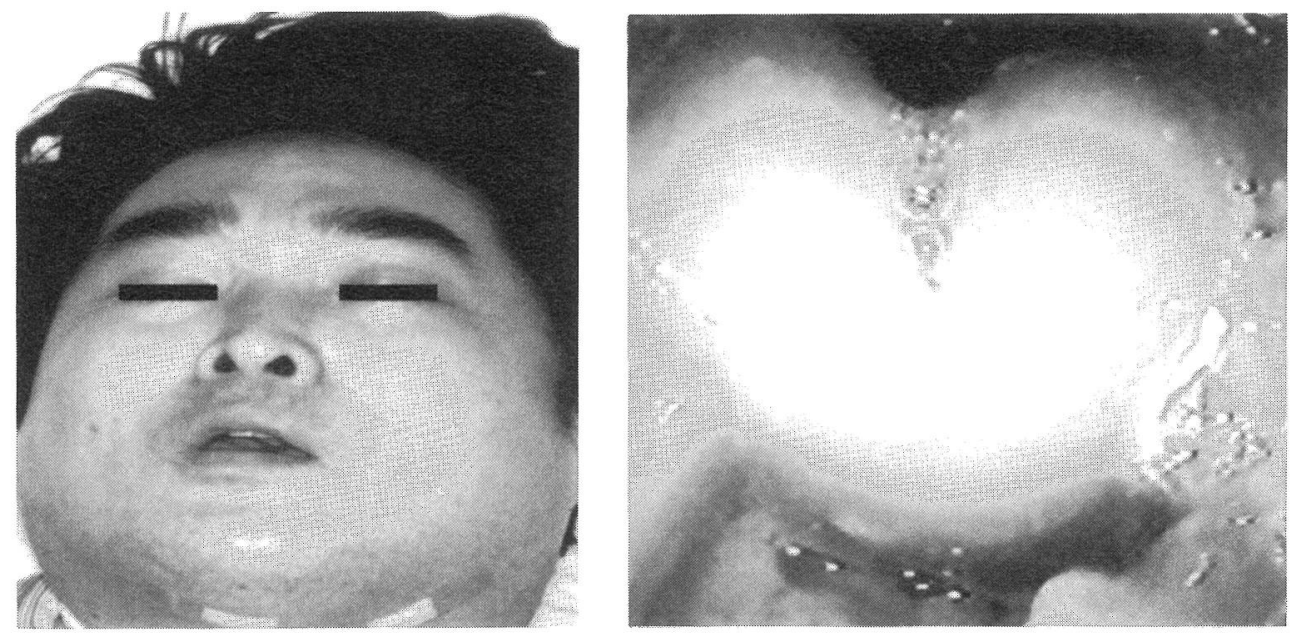

図 2 気管切開直後の所見

顔面は両耳下部，顎下部の腫脹がみられる。

喉頭所見は，初診時より浮腫が増悪している. 


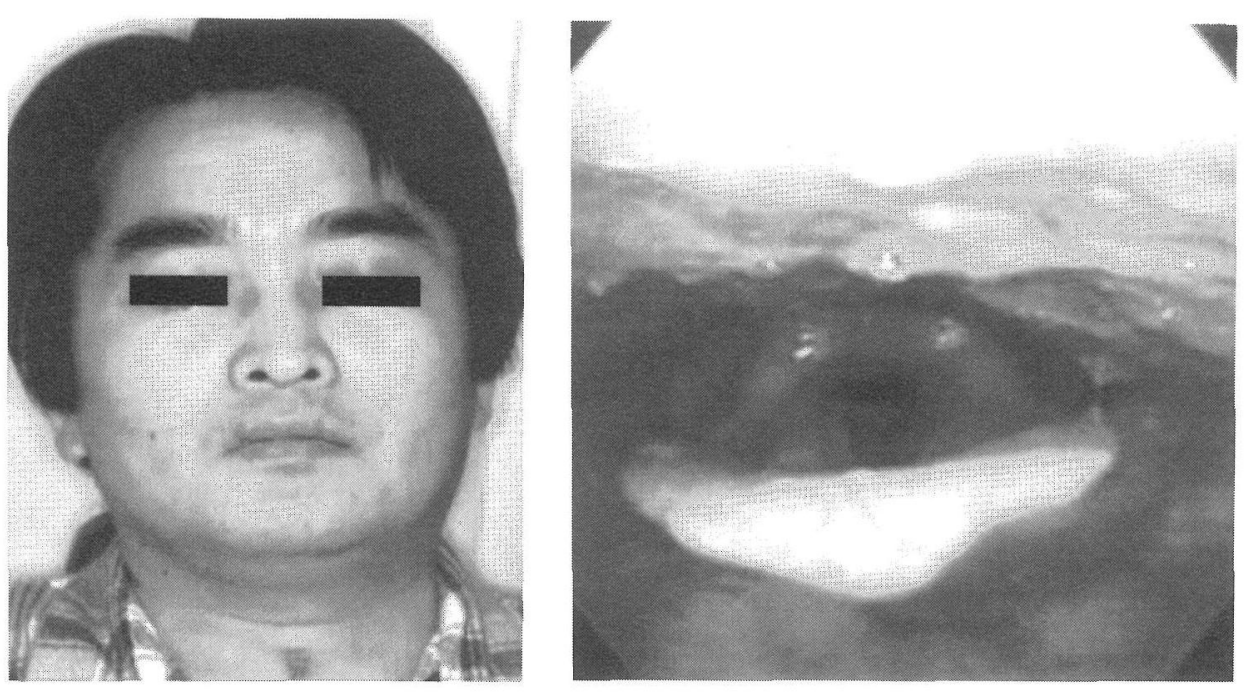

図 3 退院時の所見

顔面，喉頭所見ともに腫脹が消失している.

る。耳下腺の有痛性腫脹と発熱を主症状とするムンプス ウイルスによる全身性伝染性感染症であり，季節的には 冬加ら秋にかけての発生頻度が高いといわれている。好 発年齢は $4 \sim 10$ 歳であり, 一般的には 5 歳児にピーク があるといわれている。1 15 歳以下の小児が $85 \%$ 以上を 占めるが，6カ月未満の乳児では母体から経胎盤的に移 行した抗体を持つのでまれである。

唾液を介した飛沫感染により感染し, 鼻咽頭の粘膜上 皮で 1 次增殖した後, 所属リンパ節でさらに増殖し, ウ イルス血症を起こし全身臟器に播種される。一般的に潜 伏期間は $2 \sim 3$ 週と長く平均で 18 日である.

食欲不振，頭痛，倦急感の前駆症状をもって発症し， 通常は片側または両側の有痛性の耳下腺腫脹と発熱で発 症する。耳下腺腫脹は最初, 下澦縁に沿った方向に拡大 し, びまん性で境界不鮮明な柔らかい弾力性のある腫脹 である.耳下腺部の発赤は伴わない。耳下腺腫脹は初め 片側性で 1 ～ 2 日のらちに他側が腫脹してくることも多 い. 片側性の耳下腺腫脹のみのものが約 $25 \%$ みられ。 腫脹部分に疼痛があり, 開口, 咀緭, 嚥下に際してしば しば疼痛を伴う。耳下腺腫脹は $1 \sim 3$ 日でピークに達し, その後 $3 \sim 7$ 日でゆっくり消退していく. 腫脹の期間は $6 \sim 10$ 日くらいのものが多い. ステノン管開口部に発 赤，腫脹がみられるが，耳下腺を圧迫しても細菌感染の 場合のよらな膿の排出はなく, 分泌される液は透明であ る。痛みのため開口, 咀嚼は制限され, 唾液分泌に際し
て疼痛が増強する. 発熱は中等度で 40 度以上となること はまれである. $1 \sim 6$ 日の持続で, 耳下腺腫脹が消失す る前に解熱する。約 $20 \%$ は正常体温のままで経過する。 唾液腺の腫脹は耳下腺, 顎下腺, 舌下腺の順に頻度は少 なくなる。

\section{2. 合併症}

髄膜炎は，ムンプス中枢神経系合併症のなかで最も頻 度が高く, ムンプスの $0.5 \sim 1 \%$ に発症がみられる6). 細 胞增多はムンプスの約 $50 \sim 60 \%$ に認められる. 耳下腺 腫脹のみられた日から 3〜 5日頃に発症する例が多いが， なかには耳下腺炎を認めずに発症する例もある。症状は 持続する頭痛, 嘔吐, 発熱, 項部硬直などであり, 予後 は良好である.ムンプス脳炎は, ムンプスウイルス感染 症に起因して, 髄膜炎症状のほ办に意識障害, けいれん， 麻痺, 失語, 不随意運動を伴う場合を示し, 発症頻度は $5000 \sim 6000$ 例に 1 例程度と考えられている. 重症例は 比較的まれであり, 通常, 臨床的には約 $5 \sim 7$ 日ほどで 改善する。しかし，後遺症を残す場合むある788。

ムンプス辠丸炎は, 思春前ではまれであり, 成人では $14 \sim 35 \%$ の頻度でみら扎るという1)。多くは耳下腺腫脹 の時期に一致して, 有痛性の凨丸炎を認める.多くは片 側性であり殬丸の萎縮を伴うことはあるが，男性不妊の 原因となることはきわめてまれである。

ムンプス難聴は, 小児の片側性突発性難聴の原因とし て知られている。突発性難聴の約 $5 \sim 6 \%$ 程度にムンプ 
スが関与するともいわれている2).ムンプス難聴の頻度 は，ムンプス患者 20,000 人に 1 人とされている99. 難聴 の多くは片側性で耳下腺炎が軽快後に気づく例が多い。 耳鳴りやめまいを伴うこともある．まれではあるが，不 顕性感染に伴い, 血清学的にムンプス感染が証明された ムンプス難聴もみられる、ムンプス難聴は内耳からウイ ルスが分離された報告もあることから，ウイルスの直接 浸潤と考えられている ${ }^{10}$. 一一般には，ムンプス難聴の発 症とムンプスの重症度や合併症との相関はないといわれ ている.また，ムンプス難聴の高度感音難聴では聴力の 回復は非常に困難である.

3. ウイルス学的検査

ムンプスウイルスの感染の診断はウイルス分離が最も 直接的な診断方法である. 臨床症状の出現する $5 \sim 6$ 日 前からウイルスを排泄しており，また髄液からも臨床 症状の出現後 $5 \sim 7$ 日ぐらいはウイルス分離が可能であ る2). しかし, 煩雑であり迅速性にかけるため, 多くの ウイルス感染症の診断にはPCRを用いた遺伝子診断が可 能となっている.

一般的には, 血清学的診断が行われ, 中和 (NT) 抗体, 補体結合 (CF) 抗体, 赤血球凝集抑制 (HI) 抗体, 免疫 酵素抗体（EIA）法抗体の測定法がある. 原則的には，急 性期と回復期のペア血清の間で 4 倍以上の抗体上昇を もってムンプスウイルスの感染と診断される. NT 抗体 が最も感度が高く，特異性も優れているが，手間のかか る方法である. HI 抗体は感度が低いので信頼する結果が 得られない. (ムンプスウイルスの外被膜蛋白に対する反 応を測定する方法であるが，パラミクソウイルス群に属 するパラインフルエンザウイルスの外被膜蛋白と交差反 応を示し特異性の面で欠点がある.） CF 抗体は治瘉後 数カ月のうちに消失してしまう.

ウイルス血清学的検查のなかに EIA 法が導入され，そ の方法む確立されてきた. EIA 抗体は NT 抗体とよく相 関し, 高感度に検出可能であり, 臨床的に最も有用な検 查法とされている．また， EIA は IgG，IgM に属する抗 体を測定できる利点がある. IgG 抗体は，シングル血清 では過去のムンプス罹患の有無を，またペア血清では現 在の感染を診断できる. IgM 抗体は, 唾液腺腫脹時には すでに陽性となり，早期診断にはきわめて有効である. 急性期に単一血清しか得られなかった場合に IgM 抗体を 測定することにより診断可能となる.

4. 本症例について
今回われわれの経験した症例は臨床経過およびウイル ス血清学的診断（EIA 法による IgM 抗体，IgG 抗体のぺ ア血清の上昇）によってムンプスと診断した．喉頭浮腫 の一般的な原因として, 創傷, 熱傷, 急性炎症などによ る感染性浮腫と放射線障害, 循環障害などによる非感染 性浮腫とに大別される．本患者において咽頭痛はほとん ぞなく, 糖尿病などの易感染をきたしやすい基礎疾患も なかった。.また採血にて炎症所見む非常に軽度であった ことから喉頭浮腫は急性喉頭蓋炎などの急性炎症に起因 しているとは考えにくかった。

本例はムンプスに喉頭浮腫を合併し呼吸困難のため気 管切開を行った症例である. 文献的には $1966 \sim 2000$ 年 の 33 年間の MEDLINE と, $1987 \sim 2000$ 年の 13 年間の 医学中央雑誌にて検索を行ったが, MEDLINE では mumps 4833 例, laryngeal edema 649 件, 医学中央雑誌で はムンプス 983 件，喉頭浮腫 105 件の報告例がみられた が，ムンプスに喉頭浮腫が合併した症例は 1 例も検索で きなかった。その他,われわれが調べたなかで唯一Nelson Textbook of Pediatrics ${ }^{5)}$ にムンプスと喉頭浮腫についての 記載がみられた。これによると, 耳下腺の腫脹, 付随し て咽頭や軟口蓋の浮腫，扁桃の圧排による急性喉頭浮腫 がみられたと記載があった。われわれの症例でも喉頭 ファイバーにて舌根扁桃，下咽頭側壁が腫脹しており， 何らかの循環障害をきたしていたために起きた喉頭浮腫 であると考えられた。 ほかにまれな喉頭浮腫として常染 色体優性遺伝であり, 補体成分のインヒビター欠損ある いは機能異常により生じる遺伝性血管神経性浮腫なども 検討したが，本患者は顔面や皮膚粘膜に反復性，発作性 の浮腫をきたした既往や家族歴はなかった。

\section{まとめ}

ムンプスに喉頭浮腫を合併し, 緊急気管切開を施行し た 1 例を報告した.ムンプスの合併症としては髄膜炎, 脳炎, 辡丸炎, 難聴などが知られているが，ムンプスに 喉頭浮腫を合併した例は，Nelson Textbook of Pediatrics に唯一記載がみられる。われわれが渉猟し得た限りでは 報告例はなく，本邦初の症例と思われる. 非常にまれで はあるが，ムンプスに喉頭浮腫を合併することがあるの で, 注意が必要である.

本論文の要旨は第 63 回耳鼻咽喉科臨床学会 (平成 13 年 6 月, 沖縄）にて口演した. 


\section{参考文献}

1）木村慶子：ムンプス. 小児科診療 $54: 845 \sim 852,1991$.

2) 中山哲夫: 流行性耳下腺炎. JOHNS 16:1173 1175, 2000 .

3）上田範子, 荒牧 元：ムンプス. JOHNS 15:1856〜 1860, 1999.

4）堺 春美: 流行性耳下腺炎. 小児内科 $29: 863 \sim 866,1997$.

5) Maldonado $Y$ : Mumps. Nelson Textbook of Pediatrics. $16^{\text {th }}$ ed (ed by Richard EB, Robert MK and Hal BJ). pp 954 955, W.B. Sauders Company, Philadelphia, 2000.

6）西條正幸，藤田晃三：ムンプスウイルス．日本臨床 $55 ： 98$ 〜 103, 1997.

7) Wolinsky JS and Wharton $M$ : Mumps virus. Virology 3rd ed (ed by Stanley AP and Walter AO). pp 1243 1266, LippincottRaven, New York, 1995.
8) Plotkin SA : Mumps vaccine. Vaccines 3rd ed (ed by Stanley AP and Walter AO). pp $267 \sim 292$, WB Saunders, Philadelphia, 1999.

9) Everberg G : Deafness following mumps. Acta Otolaryngol $48: 397 \sim 403,1957$.

10) Westmore GA, Pickard $\mathrm{BH}$ and Stern $\mathrm{H}$ : Isolation of mumps virus from the inner ear after sudden deafness. Br Med J 1:14 $\sim 15,1979$.

原稿受付：平成 14 年 3 月 4 日

原稿採択：平成14年 4 月 3 日

別刷請求先 : 殿内一弘

于285-8741 佐倉市下志津564-1

東邦大学佐倉病院耳鼻咽喉科 